\title{
Non-synergistic effects of water-soluble crude oil and enhanced ultraviolet-B radiation on a natural plankton assemblage
}

\author{
Peggy Sargian' ${ }^{1}$, Behzad Mostajir ${ }^{2}$, Khaled Chatila ${ }^{3}$, Gustavo A. Ferreyra ${ }^{1,4}$, \\ Émilien Pelletier ${ }^{1, *}$, Serge Demers ${ }^{1}$ \\ ${ }^{1}$ Institut des Sciences de la Mer de Rimouski (ISMER), Université du Québec à Rimouski, 310, Allée des Ursulines, \\ Rimouski, Québec G5L 3A1, Canada \\ ${ }^{2}$ Réseaux Trophiques Pélagiques (GDR 2476) et Ecologie Microbienne des Milieux Aquatiques, UMR 5119 Écosystèmes \\ Lagunaires, CNRS, Université Montpellier II, Case 093, 34095 Montpellier Cedex 5, France \\ ${ }^{3}$ Laboratoire d'Océanographie de Villefranche, CNRS-UPMC, BP 28, 06230 Villefranche-sur-Mer, France \\ ${ }^{4}$ Instituto Antártico Argentino (IAA), Cerrito 1248, Código Postal C1010AAZ Buenos Aires, Argentina
}

\begin{abstract}
The present study demonstrates the effects of the water-soluble fraction (WSF) of a crude oil, enhanced ultraviolet-B radiation (UVBR: 280 to $320 \mathrm{~nm}$ ), and the combination of WSF and enhanced UVBR on a natural plankton assemblage $(<150 \mu \mathrm{m})$ isolated from the lower St. Lawrence Estuary. To study the separate and dual effects of WSF and UVBR, 12 microcosms (9 l) were immersed in the water column of larger mesocosms (polyethylene bags; 1800 l), providing 4 treatments, each in triplicate: (1) NUVBR + WSF (natural UVBR with WSF), (2) HUVBR + WSF (enhanced UVBR with WSF), (3) NUVBR (natural UVBR without WSF), and (4) HUVBR (enhanced UVBR without WSF). During $5 \mathrm{~d}$ we monitored the incident radiation, WSF and nutrient concentrations, abundance and production of heterotrophic bacteria and phytoplankton. Strong deleterious effects of WSF and lower effects of UVBR were observed on the phytoplankton assemblage, with a decrease in growth rates accompanied by an increase in mean cell size which reflected a perturbation of the cell division cycle. Using the NUVBR treatement as reference conditions, the above effects resulted in a reduction of 84, 79 and $60 \%$ of total abundance of the phytoplankton fraction $<20 \mu \mathrm{m}$ in the HUVBR + WSF, NUVBR + WSF and HUVBR treatments, respectively. Significant higher values of bacterial abundances were observed in the WSF-added treatments compared to NUVBR without WSF. However, bacterial thymidine incorporation exhibited diel variations, suggesting cumulative UVBR-induced DNA and/or PAHinduced DNA damages, and possible repair mechanisms with the co-occurrence of more available growth substrates from stressed phytoplankton. The absence of significant differences between both WSF-added treatments under the 2 different UVBR conditions suggests that there is no additive interaction between WSF and UVBR. This study provides therefore the first evidence of a non-synergistic interaction between both stresses, and suggests that UVBR-induced effects on marine microorganisms can be completely masked by the strong deleterious effects of soluble petroleum hydrocarbons.
\end{abstract}

KEY WORDS: Ultraviolet radiation · Dissolved hydrocarbons · Non-synergistic effect $\cdot$ Phytoplankton · Bacteria Resale or republication not permitted without written consent of the publisher

\section{INTRODUCTION}

Solar UV-B radiation (UVBR: 280 to $320 \mathrm{~nm}$ ) reaching the Earth's surface has increased during recent years due to ozone depletion and because of their importance in the global carbon cycle this has prompted research on its effects on phyto- and bacterioplankton assemblages. Several investigations have 
shown that UVBR inhibits phytoplankton photosynthesis (Vincent \& Roy 1993, Bergmann et al. 2002), growth and cell division (Karentz et al. 1991, Buma et al. 1997, Mostajir et al. 1999b), nutrient uptake (Fauchot et al. 2000, Mousseau et al. 2000), and induces changes in algal specific composition (Neale et al. 1994, Mostajir et al. 1999a,b, Wängberg et al. 2001). Bacterioplankton is also affected by UVBR in several ways, including a reduction in bacterial production (Aas et al. 1996, Chatila et al. 2001), abundance (Müller-Niklas et al. 1995), and viability (Vincent \& Roy 1993). Such plankton responses to enhanced UVBR are species-specific because of differences in UVBR sensitivity (Neale et al. 1998). Moreover, plankton responses may differ according to latitude (Longhi 2003). Indeed, UVBR shows high variability, particularly in respect to changes in solar elevation with latitude. It is therefore expected that cells are fairly UVBR-sensitive, their sensitivity varying with their light environment (Helbling et al. 1992).

Recent environmental work has focused on the toxicity induced by simultaneous exposure to natural solar radiation and environmental contaminants (Liess et al. 2001). For example, it has been demonstrated that aquatic ecosystems may be impaired through the lightmediated phototoxicity of light polycyclic aromatic hydrocarbons (PAHs) present in the water soluble fraction (WSF) of crude oil (Marwood et al. 1999). Photoactivation of PAHs by natural irradiance, especially UVBR, is one of the most important routes of their enhanced toxicity in the marine environment (Huang et al. 1993, McConkey et al. 1997). Such photoinduced toxicity results from photosensitization (with reactive oxygen-species formation) and photomodification (defined here as photooxidation and/or photolysis) processes. In the latter, photoproducts formation occurs, and these new compounds are considered to be more toxic than the initial compounds (McConkey et al. 1997, Mallakin et al. 1998).

Combined and/or synergistic effects of PAHs and UVBR exposure are therefore highly relevant in ecotoxicology, because PAHs are a prevalent group of organic contaminants in surface waters (OSB 2003). Moreover, according to current predictive models, ozone depletion will continue to occur in the years 2010 to 2019, resulting in an ozone hole over the North Pole that is perhaps as big as the present one over Antarctica (Schindell et al. 1998). It was therefore interesting to assess plankton assemblage responses to dual stresses and to determine whether these responses differ according to latitude. In this context, a series of mesocosm experiments were conducted at 2 latitudes: northern temperate (Rimouski, Canada), and southern temperate (Ushuaia, Argentina), periodically exposed to ozone hole conditions. We present here the first part of these results, which corresponds to the study of the effects of UVBR and WSF (dissolved PAHs) on a natural plankton assemblage from the St. Lawrence Estuary (Rimouski, Canada).

In the present investigation, we tested the hypothesis that elevated UVBR levels induced by the ozone depletion in northern latitudes could enhance the toxicity of the WSF of crude oil released in the euphotic layer of coastal waters in the few hours and days following an oil spill event. An outdoor microcosm approach was adopted to provide information on the interactive toxicity of the WSF and enhanced UVBR on the lower St. Lawrence Estuary plankton assemblage. A series of measurements was undertaken to characterize chemical and biological changes that occurred in the first $5 \mathrm{~d}$ after the introduction of WSF, such as hydrocarbon content, phytoplankton dynamics, as well as bacterial abundance and productivity.

\section{MATERIALS AND METHODS}

Experimental set-up. The results reported here are part of a study using large mesocosms designed to determine the effects of increased UVBR levels on a natural plankton assemblage of the lower St. Lawrence Estuary. For this general purpose, the experimental set-up (Fig. 1), consisted of 6 mesocosms (2.3 m deep, volume of $\sim 1800$ l) made of clear polyethylene bags that transmitted 85 to $93 \%$ of irradiance between 280 and $750 \mathrm{~nm}$. The bags were immersed in the water column and attached to a wharf structure in a marina on the south shore of the lower St. Lawrence Estuary, Québec, Canada $\left(48.6^{\circ} \mathrm{N}, 68.2^{\circ} \mathrm{W}\right)$.

Mesocosms were exposed in triplicate to one of the following UVBR regimes: natural UVBR (NUVBR) or high UVBR enhancement (HUVBR). UVBR enhancement was achieved using 4 fluorescent light tubes (Philips TL40W-12RS) with an emission peak at $313 \mathrm{~nm}$. They were turned on from 10:00 to $15: 00 \mathrm{~h}$ each day. Shorter wavelengths emitted by the tubes and not part of natural radiation (UVCR, $<280 \mathrm{~nm}$ ) were screened-out by means of $0.13 \mathrm{~mm}$ cellulose acetate films (Cadillac plastic) which were changed daily. To ensure equal shading effects, dummies for the tube holders were placed over NUVBR treatments. Clear polyethylene sheets were placed over each mesocosm during the night to prevent rainwater intrusion into the mesocosms. Seawater was sampled on June 17, 2000 from the St. Lawrence Estuary $\left(48.3^{\circ} \mathrm{N}\right.$, $68.3^{\circ} \mathrm{W}$ ) at $5 \mathrm{~m}$ depth, using a zooplankton water pump (Gorman-Rupp, Model 13D-19), and then transported by ship to the experimental site. Upon arrival at the marina, all 6 mesocosms were filled simultaneously. Larger zooplankton organisms and debris were dis- 


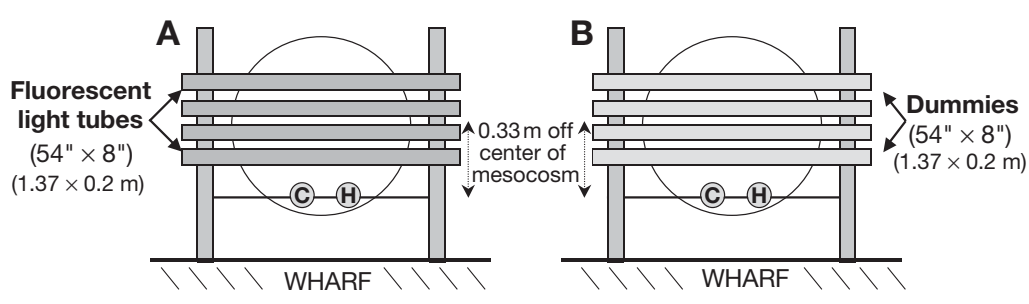

Fig. 1. Experimental set-up. (A, B) Top views showing position of microcosms inside mesocosms in (A) enhanced UV-B radiation (HUVBR) and (B) natural UV-B radiation (NUVBR) treatments. (C) Side view demonstrating positions of microcosms in water column of mesocosm (broad upright arrows on bottom right show intake and outflow of water circulation pump). C: microcosms without hydrocarbons; $\mathrm{H}$ : microcosms with hydrocarbons

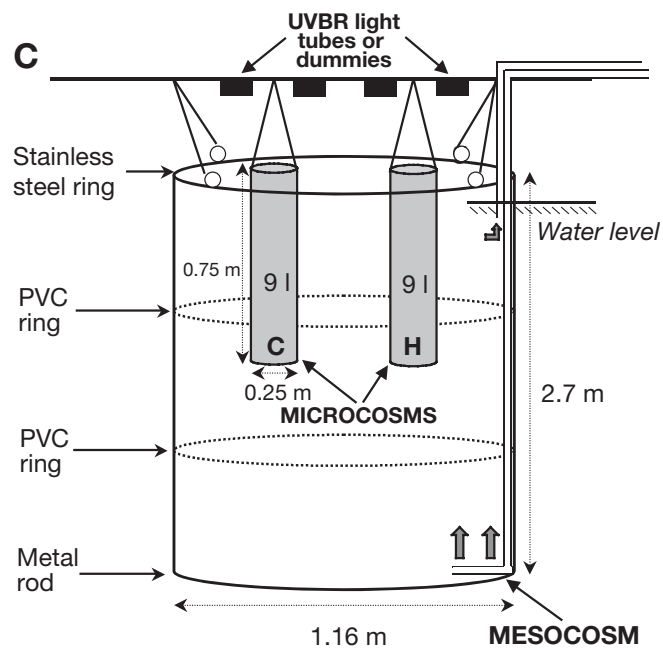

carded from the mesocosms by screening water through a $500 \mu \mathrm{m}$ Nitex $^{\mathrm{TM}}$ mesh. To ensure homogeneity within each mesocosm throughout the experiment, water was continuously mixed from the bottom to the top using a Little Giant ${ }^{\circledR}$ pump (Model 2-MD-HC) at a flow rate of $251 \mathrm{~min}^{-1}$.

To attain the specific objectives of the present research, the experiment was carried out during a $5 \mathrm{~d}$ period from 20 to 24 June 2000, using 12 microcosms (9 l cylindrical Teflon ${ }^{\circledR}$ bags: $75 \mathrm{~cm}$ height $25 \mathrm{~cm}$ width) (Fig. 1). Mesocosms were submitted to the experimental light conditions over $2 \mathrm{~d}$ (18 and 19 June) before the microcosm experiment started. Seawater (filtered through a $150 \mu \mathrm{m}$ net to exclude large grazers) was then transferred to the microcosms and WSF added. We immersed 2 microcosms at the center of each triplicated mesocosm for both NUVBR and HUVBR treatments, and filled them with water from the relevant mesocosms; one of the microcosms received WSF, the other was kept without dissolved hydrocarbons. A total of 6 microcosms were exposed to NUVBR and 6 to HUVBR. Microcosms were labelled according to their light condition and WSF addition (or otherwise): (1) NUVBR and HUVBR for microcosms without dissolved hydrocarbons, (2) NUVBR + WSF and HUVBR + WSF for microcosms with dissolved hydrocarbons added. Before each sampling, the microcosm content was manually homogenized. The water samples were siphoned out at half-depth of the water column of each microcosm twice each day.

Physical measurements in mesocosms. The incident radiation at $313,320,340$ and $380 \mathrm{~nm}$ was recorded every $10 \mathrm{~min}$ using a GUV (Biospherical Instruments) surface radiometer. Vertical light profiles were also performed at the center of each mesocosm 3 times a day (at 10:00, 12:00 and 14:30 h) using a PUV-500 (Biospherical Instruments) underwater radiometer. The PUV-500 provided a measurement of the cosine-corrected downwelling irradiance for 4 discrete channels in the UVR range $(313,320,340$ and $380 \mathrm{~nm}$ ) and PAR. Irradiance was corrected by the dark values and normalized to the ambient conditions at the beginning of the profile, using ambient values given by the GUV. The attenuation coefficient, $K_{\mathrm{d}}(\lambda), \mathrm{m}^{-1}$, was assessed in each mesocosm using the relationship:

$$
K_{\mathrm{d}}(\lambda)=\ln \left(E_{\mathrm{d} 0}-(\lambda) / E_{\mathrm{d} z}(\lambda)\right) / \lambda z
$$

where $E_{\mathrm{d} 0}-(\lambda)$ and $E_{\mathrm{dz}}(\lambda)$ are the incident irradiance beneath the water surface and at depth $z$ at wavelength $\lambda$, respectively.

Chemical measurements in microcosms. Oil contamination: The crude oil used in this study was a light Forties crude oil originating from North Sea oil fields (specific gravity of $0.839 \mathrm{~g} \mathrm{~cm}^{-3}$, viscosity of $10 \mathrm{cSt}$ at $10^{\circ} \mathrm{C}$ [following API 1986]). To prepare the WSF, $35 \mathrm{ml}$ of crude oil were floated over $3.5 \mathrm{l}$ of filtered $(0.45 \mu \mathrm{m})$ seawater into a carefully pre-cleaned glass jar. The jar was sealed and mixture stirred slowly for $48 \mathrm{~h}$ at $20^{\circ} \mathrm{C}$ without disturbing the oil/water interface. The stirring speed was adjusted so that the vortex depth did not extend $25 \%$ of the distance to the bottom of the jar. The underlying water phase (considered as the 100\% WSF hereafter) was siphoned with caution to avoid any oil droplets being sampled. WSF was quantified as described below, and then added on Day 3 to the experimental microcosms to yield a final concentration of $11 \mathrm{mg} \mathrm{l}^{-1}$.

Oil chemical analysis: Water samples $(200 \mathrm{ml})$ were collected 3 times during the experiment (Days 3, 5 and 7 ) in each microcosm with WSF added. To measure partitioning into the water column, both dissolved (i.e. passing through $0.7 \mu \mathrm{m}$ Whatman GF/F filter) and particulate (i.e. retained on the filter) phases were immediately and separately extracted twice with dichloromethane (DCM) following Siron \& Giusti (1990). Total 
aromatic hydrocarbons were analyzed by measuring the fluorescence of the extracts with a Perkin-Elmer LS 50B luminescence spectrometer, using a quartz cell and the synchronous excitation-emission technique (Wakeham 1977). Excitation-emission scans were made on the samples of interest to determine the general fluorescence characteristics of the hydrocarbons present. Excitation and emission monochromators were offset by $25 \mathrm{~nm}$, and the emission between 250 and $500 \mathrm{~nm}$ was recorded.

Thereafter, total extracts were cleaned onto a microcolumn (Supelclean ${ }^{\mathrm{TM}}$ ENVI ${ }^{\mathrm{TM}}-18$ SPE Tubes $3 \mathrm{ml}$, SUPELCO). Aromatic hydrocarbons were eluted with $8 \mathrm{ml}$ of hexane:DCM (90:10), and the eluate was concentrated under nitrogen flux to $0.1 \mathrm{ml}$. These extracts were analyzed with a gas chromatograph/mass spectrometer (GC/MS) Finnigan POLARIS Q (Thermo Quest) using a fused silica capillary column (30 $\mathrm{m} \times$ $0.25 \mathrm{~mm}$ inner diameter; Restek-5MS) with helium as carrier gas. Mass spectral data were collected over a scan range of 50 to 650 atomic mass units in the total ion mode. The initial WSF used in the microcosms was also analyzed with GC/MS. The reproducibility of the analytic method was tested with 7 successive injections of deuterated PAHs (anthracene- $\mathrm{d}_{-10}$ and pyrene- $\mathrm{d}_{10}$ ). The relative standard deviation (RSD) was $1.42 \%$.

Nutrients: Samples for nutrients (dissolved nitrate + nitrite, phosphate and silicate) were collected daily $(7: 00 \mathrm{~h})$, filtered through pre-combusted Whatman $\mathrm{GF} / \mathrm{F}$ filters and stored at $-80^{\circ} \mathrm{C}$ until analysis with a Technicon $\mathrm{II}^{\circledR}$ autoanalyser system, according to Parsons et al. (1984).

Biological measurements in microcosms and calculations. Chlorophyll a: To determine total chlorophyll a (chl a >0.7 $\mu \mathrm{m})$ concentrations, $100 \mathrm{ml}$ of seawater samples were filtered each day $(7: 00 \mathrm{~h})$ onto Whatman GF/F filters and measured with a 10-005R Turner Designs fluorometer, following a $24 \mathrm{~h}$ extraction in $90 \%$ acetone at $4^{\circ} \mathrm{C}$ (Parsons et al. 1984).

Flow cytometric analysis of phytoplankton: Flow cytometric analysis of phytoplankton cells $(<20 \mu \mathrm{m})$ collected at 07:00 and 15:00 h was performed during the experiment using a FACSORT analyzer flow cytometer (FCM, Becton-Dickinson) fitted with a 488 $\mathrm{nm}$ laser beam. Only the abundance and forwardangle light scatter (FSC, related to particle size) of phytoplankton $<20 \mu \mathrm{m}$ are reported in this study. The FSC and fluorescence signals were calibrated just before analysis using Fluoresbrite beads (Polyscience) of 2, 10 and $20 \mu \mathrm{m}$ as internal standards. Phytoplankton cells were detected using natural red fluorescence (FL3 > $650 \mathrm{~nm}$ ), which is attributed to chl a. Data were logged using Cell Quest ${ }^{\circledR}$ and then analyzed with Attractor ${ }^{\circledR}$ softwares (both from BectonDickinson).
Based on the exponential increase in the abundance observed under natural condition (NUVBR treatment), growth rates $\left(k, \mathrm{~d}^{-1}\right)$ were calculated for the period between Day 4 (D4) and the end of the experiment (D7) as follows:

$$
k=\frac{\ln N_{\mathrm{D} 7}-\ln N_{\mathrm{D} 4}}{\mathrm{D} 7-\mathrm{D} 4}
$$

where $N_{\mathrm{D} 7}$ and $N_{\mathrm{D} 4}$ are cell numbers at final time D7 and initial time D4 of the exponential phase observed under NUVBR treatment, respectively.

Bacterial enumeration and activity $\left({ }^{3} \mathrm{H}\right.$-thymidine incorporation): Bacterial counts were done from samples stained with 4'6 diamidino-2-phenolindole, DAPI (Sigma). First, $10 \mathrm{ml}$ samples were placed onto a $25 \mathrm{~mm}$ diameter filtration apparatus fitted with $0.2 \mu \mathrm{m}$ pore-size, black, polycarbonate membrane filters (Poretics). Upon filtration of approximately half the sample, $50 \mu \mathrm{g} \mathrm{l}^{-1}$ DAPI were added to the concentrated residuals and held in the dark for $30 \mathrm{~min}$. After filtration to dryness, dry filters were mounted on slides with a drop of immersion oil. Bacterial abundances were then counted using a Zeiss ${ }^{\circledR}$ epifluorescence microscope.

To assess bacterial productivity, the use of radiolabelled precursor molecules such as ${ }^{3} \mathrm{H}$-thymidine is a common method (TdR; Fuhrman \& Azam 1982). The method is based on the assumption that exogenously supplied ${ }^{3} \mathrm{H}$-TdR is taken up by actively growing bacteria and incorporated into DNA, and is therefore used to estimate DNA synthesis (Aas et al. 1996). Thus, bacterial production was measured using the ${ }^{3} \mathrm{H}-\mathrm{TdR}$ (Sigma; specific activity $3.710^{7} \mathrm{~Bq} \mathrm{ml}^{-1}$ or $1.0 \mathrm{mCi} \mathrm{ml}^{-1}$ ) incorporation technique according to Smith \& Azam (1992), and using microcentrifugation instead of filtration. From each microcosm, samples were taken at 7:00 and 15:00 h during each day of the experiment, inoculated with ${ }^{3} \mathrm{H}$-TdR and incubated at ambient temperature in the laboratory for $1 \mathrm{~h}$. Glutaraldehyde was then added to stop the reaction. Samples were processed immediately after the end of incubation and checked for dpm counts using a Beckman Liquid Scintillation System 3801 series. Sample activity was converted into volume-dependent rates of thymidine incorporation (total activity, TA; pmol TdR $\mathrm{l}^{-1} \mathrm{~h}^{-1}$ ) according to Furhman \& Azam (1982). The TA was normalized to bacterial abundance to estimate the cell-specific incorporation of ${ }^{3} \mathrm{H}$ TdR (specific activity, SA; pmol TdR cell ${ }^{-1} \mathrm{~h}^{-1}$ ).

Statistical analyses. A repeated-measure multivariate analysis of variance (MANOVA) was conducted to assess time effects and time $\times$ treatment interactions on the different parameters measured (Scheiner \& Gurevitch 1993). MANOVA requires multivariate normality and homogeneity of covariance matrices. Preliminary data using the Kolmogorov-Smirnov test indicated that 
all data fit a normal distribution. For the latter assumption, even after logarithmic transformation to normalize the residuals and homogenize variances, the symmetry of the covariance matrices did not meet this assumption of MANOVA for some parameters and so the F-statistics were inflated. The standard provision is to reduce the degrees of freedom in the F-test, and the HuynhFeldt (H-F) adjustment was applied; therefore, H-F corrected $p$ values were used (Scheiner \& Gurevitch 1993).

Thereafter, a 2-factor ANOVA (UVBR and WSF) was applied each day to determine the significance of the differences among means as well as the significance of the interactions (UVBR $\times \mathrm{WSF}_{\text {; }}$ time-independent). A post-hoc, pairwise, multiple-comparison Tukey test was then performed at each sampling time in order to detect significant differences between treatments and reveal possible combined effects between UVBR and dissolved hydrocarbons.

\section{RESULTS}

\section{Light and UVBR irradiances}

The general meteorological conditions are described using the data provided by a GUV instrument (313, $380 \mathrm{~nm}$, and the photosynthetically active radiation, PAR, range). During this experiment, there were $6 \mathrm{~d}$ of clear sky, and 1 d $100 \%$ overcast (Day 4) (Fig. 2A). The plankton assemblage received the same proportion of the daily incident irradiance under the 4 different treatments. The daily-integrated radiation doses (natural or enhanced) received just below the water surface are given in Table 1 for different UV radiation wavelengths. Compared to the NUVBR treatment, the enhancement provided by lamps was highest for the shorter wavelengths and decreased with increasing wavelength. The average enhancement at $313 \mathrm{~nm}\left(1.25 \mathrm{~kJ} \mathrm{~m}^{-2}\right.$ $\left.\mathrm{d}^{-1}\right)$ was higher than at $320 \mathrm{~nm}\left(1.17 \mathrm{~kJ} \mathrm{~m}^{-2}\right.$ $\left.\mathrm{d}^{-1}\right)$ and far higher than at $380 \mathrm{~nm}\left(0.51 \mathrm{~kJ} \mathrm{~m}^{-2}\right.$ $\mathrm{d}^{-1}$ ). The mean enhanced UVBR levels in the HUVBR treatments, based on $313 \mathrm{~nm}$ wavelength, was calculated by subtracting the value of the $313 \mathrm{~nm}$ wavelength observed in the NUVBR from those measured in the HUVBR treatments. The mean unweighted $313 \mathrm{~nm}$ in the HUVBR treatments was 1.59fold higher than that in the NUVBR treatments.

To support the biological significance of lamp enhancement, the biological weighting function (BWF) of Cullen et al. (1992) was
Table 1. Mean integrated daily irradiances at $313,320,340$, and $380 \mathrm{~nm}$, on sunny days just below water surface in NUVBR (natural UV-B radiation) and HUVBR (enhanced UV-B radiation) treatments

\begin{tabular}{|lcc|}
\hline $\begin{array}{l}\text { Radiation wavelength } \\
(\mathrm{nm})\end{array}$ & $\begin{array}{c}\text { NUVBR } \\
\left(\mathrm{kJ} \mathrm{m}^{-2} \mathrm{~d}^{-1}\right)\end{array}$ & $\begin{array}{c}\text { HUVBR } \\
\left(\mathrm{kJ} \mathrm{m}^{-2} \mathrm{~d}^{-1}\right)\end{array}$ \\
\hline 313 & $2.15 \pm 0.14$ & $3.40 \pm 0.11$ \\
320 & $3.42 \pm 0.34$ & $4.59 \pm 0.28$ \\
340 & $7.36 \pm 0.61$ & $8.27 \pm 0.58$ \\
380 & $8.78 \pm 0.75$ & $9.29 \pm 0.74$ \\
\hline
\end{tabular}

applied (Table 2). For this, the $313 \mathrm{~nm}$ value was scaled to the whole light spectrum. The weighted irradiance in the 280 to $320 \mathrm{~nm}$ range was 2.15-fold greater in the HUVBR treatment than in the NUVBR treatment.

$K_{\mathrm{d}}$ values did not vary significantly among mesocosms during the experiment. UVR attenuation coefficients $\left(K_{\mathrm{d}}, \mathrm{m}^{-1}\right)$ ranged from $4.86(313 \mathrm{~nm})$ to $1.95 \mathrm{~m}^{-1}$ $(380 \mathrm{~nm})$, with the mean depth of $1 \%$ of surface irradi-
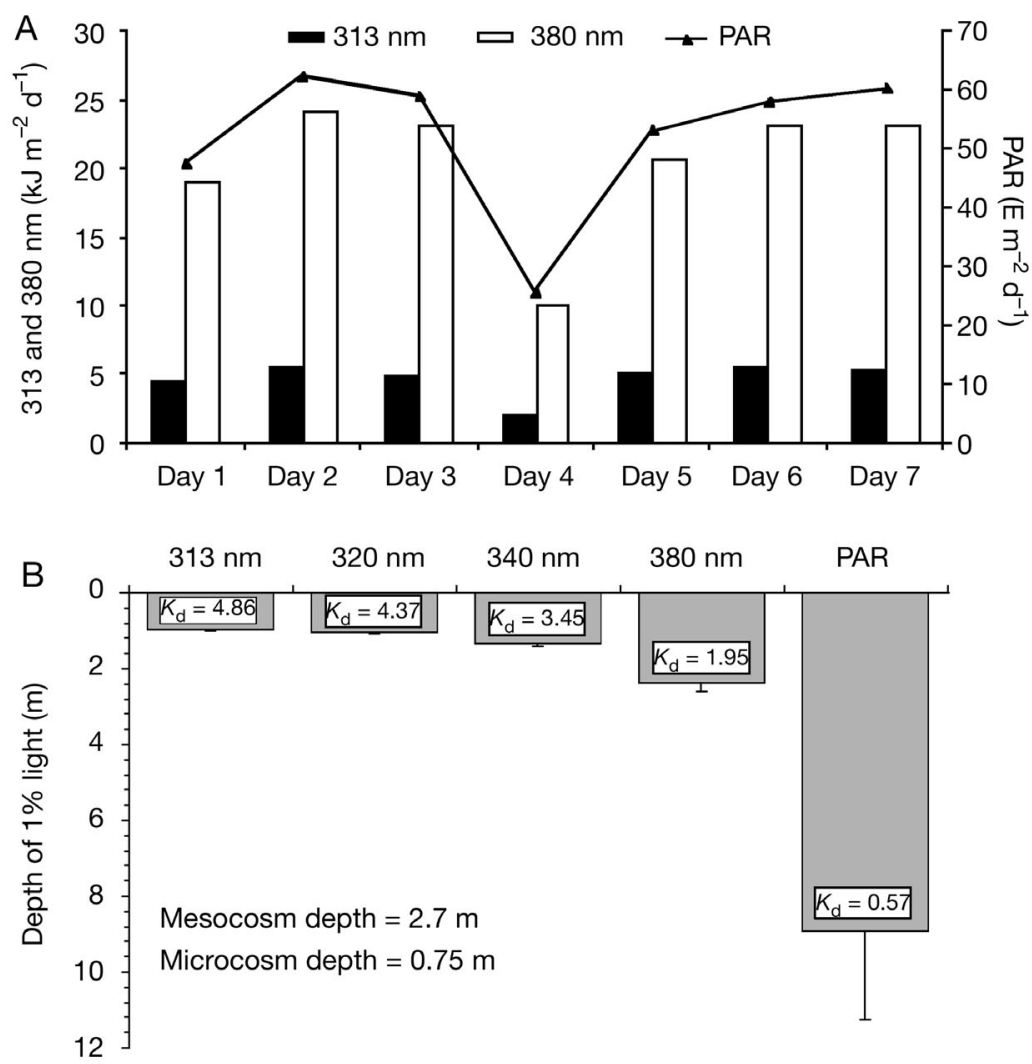

Fig. 2. Daily integrated incident irradiance at 313 and $380 \mathrm{~nm}$ and at photosynthetically active radiation (PAR) measured over $7 \mathrm{~d}$ period of experiment, illustrating general meteorological conditions. (B) Apparent attenuation coefficients $\left(K_{\mathrm{d}}, \mathrm{m}^{-1}\right)$ for $313,320,340$ and $380 \mathrm{~nm}$ and for PAR, derived from irradiance depth profiles in the mesocosms; the corresponding depth $(+\mathrm{SD})$ of $1 \%$ near-surface irradiance $(0 \mathrm{~m})$ at each wavelength is indicated by the bars 


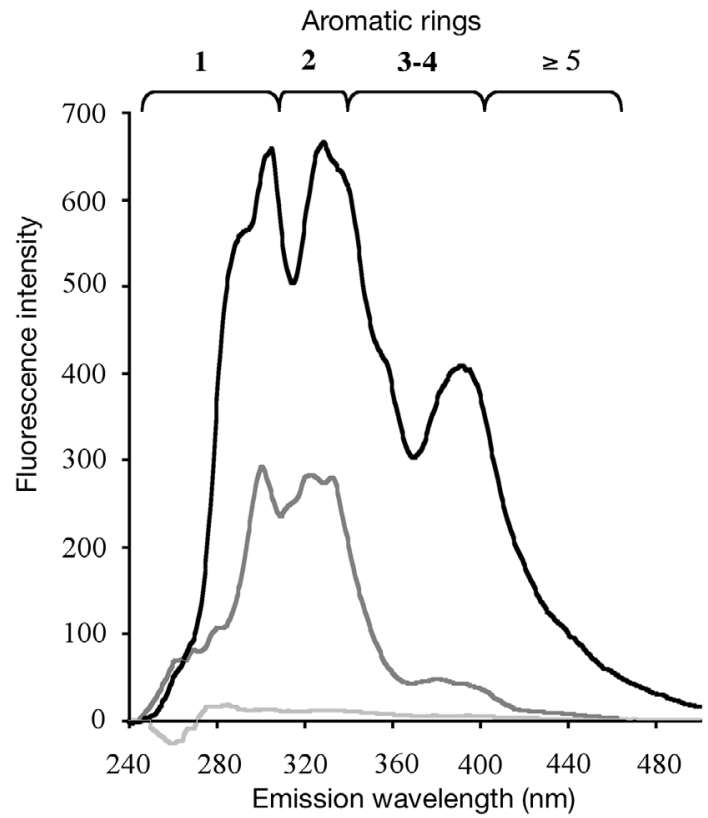

Fig. 3. Synchronous fluorescence spectra of Forties crude oil (top line), initial water-soluble fraction (middle line), and initial sampling water (bottom line). Assignment of major peaks from Wakeham's data (1977). Scan excitation-emission wavelengths $=250$ to $500 \mathrm{~nm}$
Table 2. Relative irradiance $\left(\mathrm{W} \mathrm{m}^{-2}\right)$ increase in HUVBR treatment using 4 fluorescent light tubes compared to relative increase in irradiance associated with ozone depletion over Antarctica. Spectral irradiance was weighted with the biological weighting function (BWF) for inhibition of photosynthesis in the temperate latitude diatom Phaeodactylum sp. (Cullen et al. 1992). HUVBR data from PUV-500 underwater radiometer (present study); McMurdo Sound data from Cullen \& Neale (1997)

\begin{tabular}{|c|c|c|}
\hline \multirow[t]{2}{*}{ Parameter } & \multicolumn{2}{|c|}{ Incident solar irradiance for } \\
\hline & McMurdo & HUVBR \\
\hline Unweighted UVBR & 1.06 & 1.59 \\
\hline $\begin{array}{l}\text { BWF for inhibition of photo- } \\
\text { synthesis (Cullen et al. 1992) }\end{array}$ & 1.24 & 2.15 \\
\hline
\end{tabular}

late fractions collected in the HUVBR + WSF treatment (Fig. 4D). This shift in fluorescence emission and its intensity could be indicative of a drastic change in the chemical composition of the WSF with the lost of major light PAHs and the possible generation of new aromatic moieties fluorescing in shorter wavelengths.

GC/MS analysis confirmed the above findings and revealed that WSF generated by Forties crude oil was mainly formed by naphthalenes (over $97 \%$ of total), as identified by their mass spectra (Table 3 ). These results ance occurring at $0.95 \mathrm{~m}(313 \mathrm{~nm}), 1.05 \mathrm{~m}$ $(320 \mathrm{~nm}), 1.34 \mathrm{~m}(340 \mathrm{~nm})$ and $2.38 \mathrm{~m}(380$ nm) (Fig. 2B).

\section{Chemical parameters}

Oil contamination

Synchronous fluorescence spectra obtained for the Forties crude oil and WSF (Fig. 3) clearly show that the WSF essentially consisted of mono- and di-aromatics with a low contribution from heavier compounds. Maximum fluorescence emission around $320 \mathrm{~nm}$ is characteristic of naphthalene and its alkylated analogs. Synchronous fluorescence spectra of samples (Fig. 4) exhibit clear differences with respect to UVBR treatments and elapsed time. Under the HUVBR + WSF treatment (both dissolved and particulate samples), fluorescence spectra showed a relative enrichment in small and fluorescent compounds (located approximately between 260 and $280 \mathrm{~nm}$ ) which was not observed under the NUVBR + WSF treatment. Changes were time-dependent, as illustrated by particu-
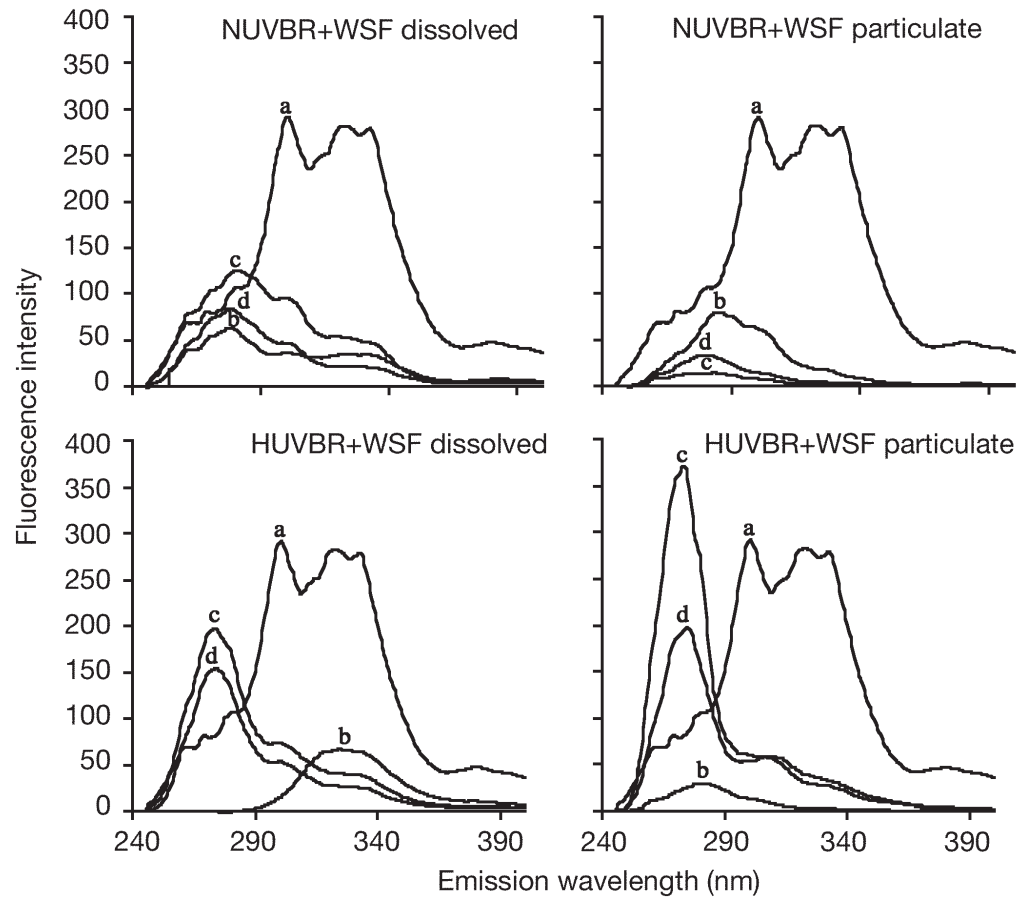

Fig. 4. Synchronous fluorescence spectra of total dissolved hydrocarbons in (A) natural UV-B radiation plus water-soluble fraction (NUVBR+WSF), and (B) enhanced UV-B radiation plus WSF (HUVBR+WSF) treatments, and of particulate hydrocarbons in (C) NUVBR+WSF, and (D) HUVBR+WSF treatments. a: initial WSF; b: Day 3; c: Day 5; d: Day 7 
support and explain the initial WSF spectra obtained by fluorescence (Figs. $3 \& 4 \mathrm{~A}$ ). As expected from their low water-solubility, $n$-alkanes were not been detected in the WSF. The level of monomethyl-naphthalene was approximatively 3 times the level of naphthalene itself, and represented around $54 \%$ of the total PAHs in WSF. Heavier PAHs were also present in the WSF, but in relative small amounts. Fluorene, anthracene, phenanthrene and its alkylated homologs were identified, but fluoranthene and pyrene were not detected.

Naphthalene and others aromatics were not detected in samples extracted during the course of the experiment because of their very low concentrations (naphthalene method limit detection $=4.5 \times 10^{-3} \mathrm{\mu g} \mathrm{l}^{-1}$; Table 3 ).

Nutrients. Nitrate + nitrite concentrations decreased from $14.15 \pm 0.05$ to $10.52 \pm 0.85 \mu \mathrm{mol} \mathrm{l}^{-1}$ from Days 1 to 5 without any significant differences between treatments (Fig. 5A). MANOVA results showed that day $\times$ WSF had a significant effect $(p<0.001)$, whereas no day $\times$ UVBR effects were recorded $(p>0.05)$. On Days 6 and 7 , significant differences $(p<0.05)$ appeared when nitrate + nitrite concentrations fell below $0.012 \mu \mathrm{mol} \mathrm{l}^{-1}$ (detection limit) for NUVBR and HUVBR
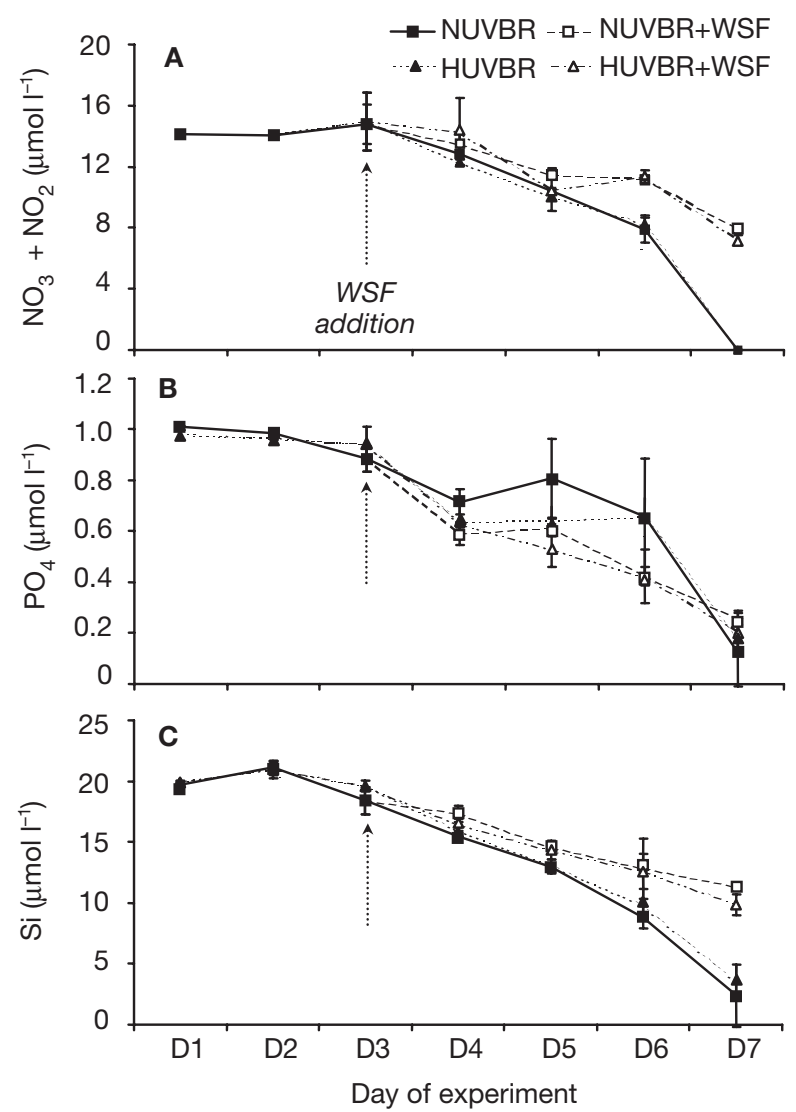

Fig. 5. Temporal changes (means $\pm \mathrm{SD}$ ) in (A) nitrite + nitrate, (B) phosphate and (C) silicate concentrations. Here and in Figs. 6 to 9, vertical arrows indicate water transfer from mesocosms to microcosms and WSF addition on Day 3
Table 3. Compounds identified in initial water-soluble fraction (WSF) from crude oil Forties before addition to microcosms. m/z: specific mass-to-charge ratio; MDLs: method detection limits

\begin{tabular}{|lccrc|}
\hline $\begin{array}{l}\text { Compounds } \\
\text { (initial WSF) }\end{array}$ & $\begin{array}{c}\text { Ring } \\
(\text { No.) }\end{array}$ & $\begin{array}{c}\mathrm{m} / \mathrm{z} \\
\text { (target ion) }\end{array}$ & $\begin{array}{c}\text { Conc. } \\
\left(\mu \mathrm{g} \mathrm{l}^{-1}\right)\end{array}$ & $\begin{array}{c}\text { MDSLs } \\
\left(\mu \mathrm{l}^{-1}\left[\times 10^{-3}\right]\right)\end{array}$ \\
\hline Naphthalene & 2 & 128 & 4.330 & 4.500 \\
C1-naphthalene & 2 & 142 & 10.028 & 15.000 \\
C2-naphthalene & 2 & 156 & 1.290 & 15.000 \\
C3-naphthalene & 2 & 170 & 2.490 & 15.000 \\
C4-naphthalene & 2 & 184 & 0.056 & 15.000 \\
Fluorene & 3 & 166 & 0.085 & 5.300 \\
Anthracene & 3 & 178 & 0.111 & 5.100 \\
Phenanthrene & 3 & 178 & 0.132 & 5.700 \\
C1-phenanthrene & 3 & 192 & 0.047 & 15.000 \\
C2-phenanthrene & 3 & 206 & 0.029 & 15.000 \\
C3-phenanthrene & 3 & 220 & 0.000 & 15.000 \\
Fluoranthene & 4 & 202 & 0.000 & 6.700 \\
Pyrene & 4 & 202 & 0.000 & 6.900 \\
Total PAHs & & & 18.598 & \\
& & & & \\
\hline
\end{tabular}

without WSF, whereas much higher concentrations $\left(7.96 \pm 0.25\right.$ and $\left.7.18 \pm 0.32 \mu \mathrm{mol} \mathrm{l}^{-1}\right)$ remained for NUVBR + WSF and HUVBR + WSF, respectively.

Phosphate concentrations measured at the beginning of the experiment were $0.99 \pm 0.02 \mu \mathrm{mol} \mathrm{l}^{-1}$, with no significant differences between treatments until Day $5\left(0.63 \pm 0.12 \mu \mathrm{mol} \mathrm{l}^{-1}\right)$ (Fig. $\left.5 \mathrm{~B}\right)$, when MANOVA detected a day $\times$ WSF effect $(p<0.05)$ only; thereafter, a significant difference was observed only on Day 6 between treatments without dissolved hydrocarbons $\left(0.66 \pm 0.23 \mu \mathrm{mol} \mathrm{l}^{-1}\right.$ for NUVBR and $0.66 \pm 0.07 \mu \mathrm{mol}$ $\mathrm{l}^{-1}$ for HUVBR) and treatments with dissolved hydrocarbons $\left(0.43 \pm 0.11 \mu \mathrm{mol} \mathrm{l}^{-1}\right.$ for NUVBR + WSF and $0.42 \pm 0.04 \mu_{\mathrm{mol} \mathrm{l}} \mathrm{l}^{-1}$ for HUVBR + WSF). Final phosphate concentrations ranged between $0.13 \pm 0.02$ and $0.26 \pm 0.03 \mu \mathrm{mol} \mathrm{l}^{-1}$, without any significant differences between treatments.

Silicate concentrations decreased steadily during the course of the experiment (Fig. 5C), and significant differences $(p<0.05)$ appeared from Day 4 to the end of the experiment, with final concentrations being much lower for NUVBR $\left(2.39 \pm 0.03 \mu \mathrm{mol} \mathrm{l}^{-1}\right)$ and HUVBR $\left(3.46 \pm 1.33 \mu \mathrm{mol} \mathrm{l^{-1 }}\right)$ treatments than for NUVBR + WSF $\left(11.33 \pm 0.05 \mu \mathrm{mol} \mathrm{l}^{-1}\right)$ and HUVBR + WSF $\left(9.87 \pm 0.84 \mu \mathrm{mol} \mathrm{l}^{-1}\right)$ treatments, with significant MANOVA results for day $\times$ WSF effects $(p<0.001)$.

\section{Biological parameters}

\section{Chlorophyll a concentrations}

The concentration of chl a was used as the main indicator of the total autotrophic biomass in the experi- 


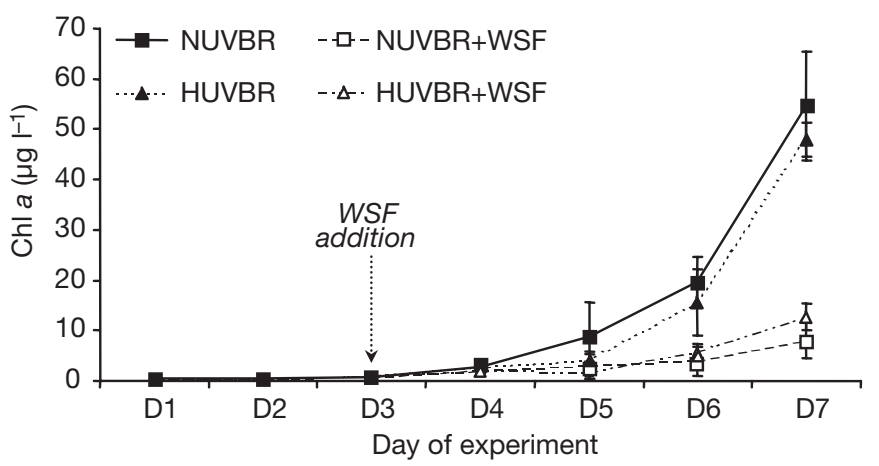

Fig. 6. Temporal changes in (means $\pm \mathrm{SD}$ ) in total chlorophyll a concentrations

ment. Chl a concentrations increased from Day 1 (0.58 $\pm 0.05 \mu \mathrm{g} \mathrm{l}^{-1}$ ) to the end of the experiment (Fig. 6). Concentrations reached final values of $54.7 \pm 10.9$ and 48.0 $\pm 3.3 \mu \mathrm{g} \mathrm{l}^{-1}$ in NUVBR and HUVBR, respectively, without day $\times$ UVBR effects $(p>0.05)$. Chl a concentration was significantly lower $(\mathrm{p}<0.01)$ when WSF was present under both UVBR conditions (NUVBR + WSF: 8.1 $\pm 3.5 \mu \mathrm{g} \mathrm{l}^{-1} ; \mathrm{HUVBR}+\mathrm{WSF}: 12.6 \pm 2.6 \mu \mathrm{g}^{-1}$ ) (day WSF $\times$ effects; $p<0.01$ ). No significant differences were observed between NUVBR and HUVBR treatments.

\section{Dynamics of phytoplankton}

The total abundance of phytoplankton $<20 \mu \mathrm{m}$ in the mesocosms varied slightly (ca. 1 to 31000 cells ml ${ }^{-1}$ ) in the first $3 \mathrm{~d}$, with no significant differences between NUVBR and HUVBR treatments (Fig. 7). However, after transferring the samples to the microcosms and the WSF addition on Day 3, MANOVA showed significant day $\times$ WSF and day $\times$ UVBR effects $(p<0.001)$ on

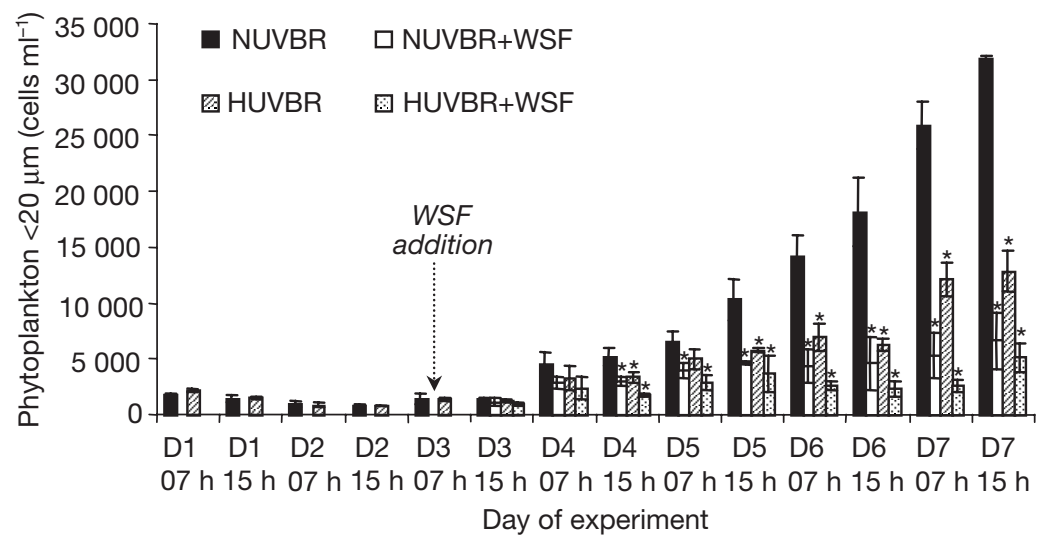

Fig. 7. Temporal changes (means \pm SD) in total abundance of phytoplankton cells $<20 \mu \mathrm{m}$, determined by flow-cytometry. *: significant differences ( $\mathrm{p}<$ 0.05 ) between treatments and relative to NUVBR (standard) the total abundance of phytoplankton $<20 \mu \mathrm{m}$, but no significant interaction between both stresses with time. A negative and significant effect $(p<0.05)$ on the total abundance of phytoplankton $<20 \mu \mathrm{m}$ was then observed from Day 4 (15 h) to the end of the experiment for all treatments relative to the NUVBR treatment. On the last day, the total abundance of phytoplankton $<20 \mu \mathrm{m}$ was 60,79 and $84 \%$ lower in the HUVBR, NUVBR + WSF, and HUVBR + WSF treatments, respectively, than in the NUVBR without WSF treatment.

In the absence of dissolved hydrocarbons and during the last days of the experiment, the higher total abundance of phytoplankton $<20 \mu \mathrm{m}$ in the NUVBR treat-

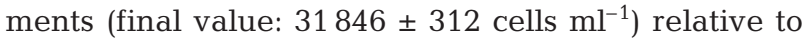
the HUVBR treatments (final value: $12852 \pm 1797$ cells $\mathrm{ml}^{-1}$ ) underlines a deleterious impact of UVBR on the smallest fraction of the assemblage $(<20 \mu \mathrm{m})$. Indeed, the data on the total chl a concentrations versus the total abundance of cells $<20 \mu \mathrm{m}$ highlight the fact that large diatoms ( $>20 \mu \mathrm{m}$ ) were not affected by enhanced UVBR levels. The addition of dissolved hydrocarbons to HUVBR lowered the total abundance of phytoplankton $<20 \mu \mathrm{m}$ to $5124 \pm 1316$ cells $\mathrm{ml}^{-1}$ (HUVBR + WSF), whereas the addition of dissolved hydrocarbons to NUVBR resulted in a final total abundance of $6625 \pm$ 2508 cells ml ${ }^{-1}$ (NUVBR + WSF). However, no significant difference was observed between the 2 treatments during the experiment.

\section{Cell size changes}

The forward-scatter (FSC) signal in cytometric analysis is generally used as an indicator of particle size (Mostajir et al. 1999a). According to cellular characteristics measured with flow-cytometry, 2 dominant groups were distinguished among the $<20$ $\mu \mathrm{m}$ phytoplankton: small (1 to $3 \mu \mathrm{m}$ ) picoautotroph cells, and large (3 to $10 \mu \mathrm{m})$ nanoautotroph cells (Fig. 8). Picoautotrophs in the NUVBR treatments were of lower size than those in the HUVBR treatments from Days 4 to 6 (Fig. 8A). These differences were also significant on the afternoon of Day 6, when WSF was present. For nanoautotrophs, HUVBR + WSF displayed significantly higher values toward the end of the experiment, and NUVBR without WSF its lowest value (Fig. 8B). MANOVA showed only a day $\times$ WSF effect $(p<0.05)$ on these cellular characteristics.

In summary, cell-size variations showed that cells were larger in the HUVBR treat- 


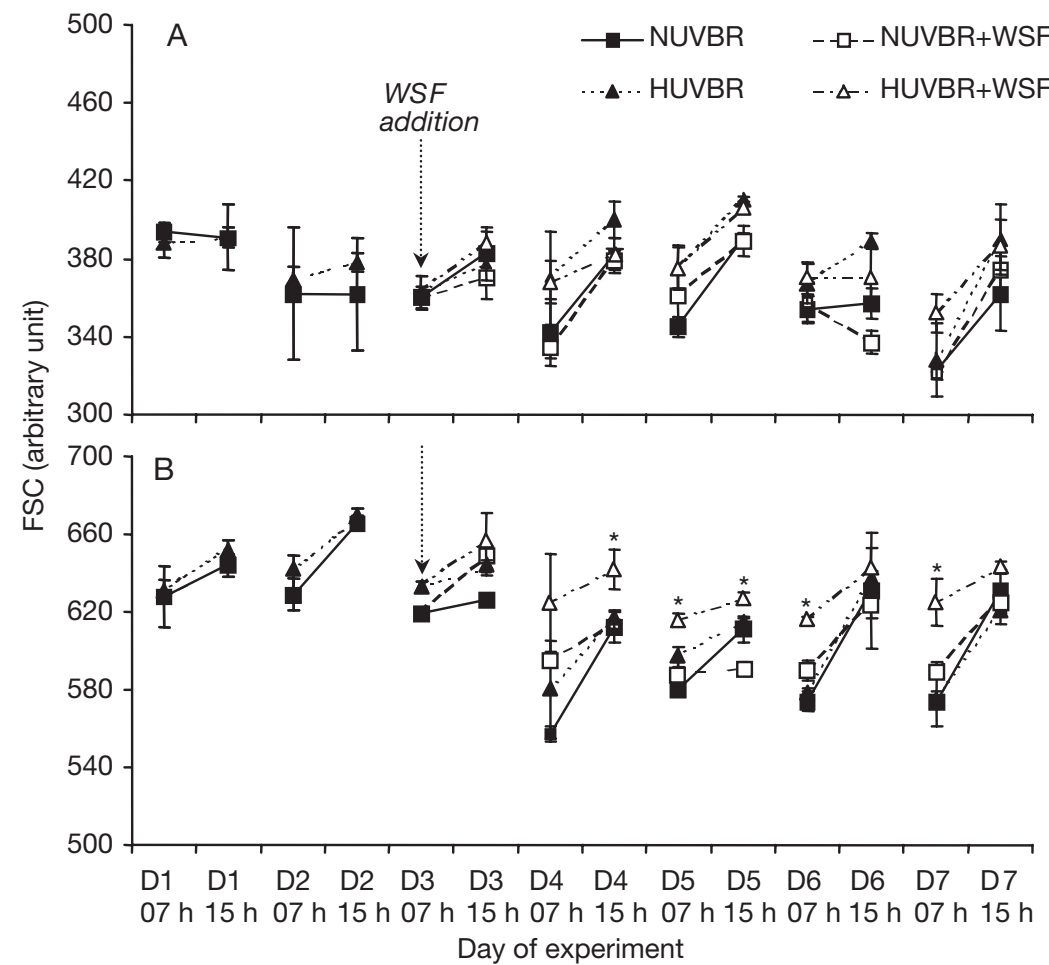

Fig. 8. Temporal changes (means $\pm \mathrm{SD}$ ) in forward scatter (FSC, cell size) for (A) 1 to $3 \mu \mathrm{m}$, and (B) 3 to $10 \mu \mathrm{m}$ fractions of phytoplankton. *: significant differences $(p<0.05)$ between HUVBR + WSF and all other treatments when no additional stress was considered other than exposure to natural sunlight (Table 4). A general pattern emerged with higher growth rates in NUVBR $(0.26 \pm 0.03$ $\left.\mathrm{d}^{-1}\right)$ followed by HUVBR $\left(0.18 \pm 0.05 \mathrm{~d}^{-1}\right)$, NUVBR + WSF $\left(0.11 \pm 0.02 \mathrm{~d}^{-1}\right)$, and finally HUVBR + WSF $\left(0.10 \pm 0.04 \mathrm{~d}^{-1}\right)$, for which the lowest values were recorded. Both WSF-added treatments produced significant lower values than the NUVBR treatment for all fractions considered.

Moreover, the nanoautotroph assemblage exhibited a greater inhibition than the picoautotroph assemblage in all treatments compared to NUVBR. Inhibition values were highest for the HUVBR + WSF treatment, with values of up to $95 \%$, compared to $81 \%$ inhibition in NUVBR + WSF, relative to natural conditions (NUVBR treatment). No significant difference was observed between these 2 WSF-added treatments.

Bacterial abundance and incorporation of ${ }^{3} \mathrm{H}-\mathrm{TdR}$

Bacterial abundance in the 4 treatments at the beginning of the experiment was < $0.2 \times 10^{6}$ cells $\mathrm{ml}^{-1}$. Then, bacteria ment than those exposed to NUVBR, and that cells subjected to HUVBR + WSF treatment were also larger than those subjected to NUVBR + WSF treatment, particularly for nanoautotrophs; however significant differences were only observed between the NUVBR and the HUVBR + WSF treatments.

\section{Growth rate}

Based on the exponential increase in their abundance observed under natural irradiance conditions (NUVBR treatment for Days 4 and 7) (Fig. 7), growth rates ranged between $0.22 \pm 0.06$ and $0.28 \pm 0.02 \mathrm{~d}^{-1}$ for nanoautotrophs and picoautotrophs, respectively, increased up to the afternoon of Day 6 in all treatments (Fig. 9A). Furthermore, for Days 5 and 6, NUVBR + WSF and HUVBR + WSF treatments showed significant higher $(\mathrm{p}<0.05)$ bacterial abundance $\left(2.76 \times 10^{6}\right.$ and $2.47 \times 10^{6}$ cells $\mathrm{ml}^{-1}$, respectively) than NUVBR and HUVBR without WSF $\left(1.7 \times 10^{6}\right.$ and $2.17 \times 10^{6}$ cells $\mathrm{ml}^{-1}$, respectively). On Day 7 , bacterial abundance increased in both HUVBR treatments whereas it decreased to $1.15 \times 10^{6}$ and $0.63 \times 10^{6}$ cells ml ${ }^{-1}$ in NUVBR and NUVBR + WSF, respectively. The differences were significant $(p<0.05)$ between all treatments at the end of the experiment relative to the NUVBR treatment. MANOVA detected significant day $\times$ WSF and day $\times$ UVBR effects $(p<0.01)$, but no day $\times$ WSF $\times$ UVBR effects.

Table 4. Growth rates $\left(k, \mathrm{~d}^{-1}\right.$ means $\left.\pm \mathrm{SD}\right)$ calculated during exponential phase for all phytoplankton assemblages; \% inhibition relative to NUVBR indicated in parentheses. ${ }^{*}$ : significant difference $(p<0.05)$ between treatments and relative to NUVBR (standard). Treatments as in legend to Fig. 4

\begin{tabular}{|lcccc|}
\hline Size group & NUVBR & NUVBR+WSF & HUVBR & HUVBR+WSF \\
\hline Total cells $<20 \mu \mathrm{m}$ & $0.26 \pm 0.03$ & $0.11 \pm 0.02^{*}(-57 \%)$ & $0.18 \pm 0.05(-30 \%)$ & $0.10 \pm 0.04^{*}(-60 \%)$ \\
$1-3 \mu \mathrm{m}$ cells (picoautotrophs) & $0.28 \pm 0.02$ & $0.17 \pm 0.02^{*}(-38 \%)$ & $0.25 \pm 0.03(-13 \%)$ & $0.15 \pm 0.04^{*}(-47 \%)$ \\
$3-10 \mu \mathrm{m}$ cells (nanoautotrophs) & $0.22 \pm 0.06$ & $0.04 \pm 0.01^{*}(-81 \%)$ & $0.15 \pm 0.06(-35 \%)$ & $0.01 \pm 0.03^{*}(-95 \%)$ \\
\hline
\end{tabular}



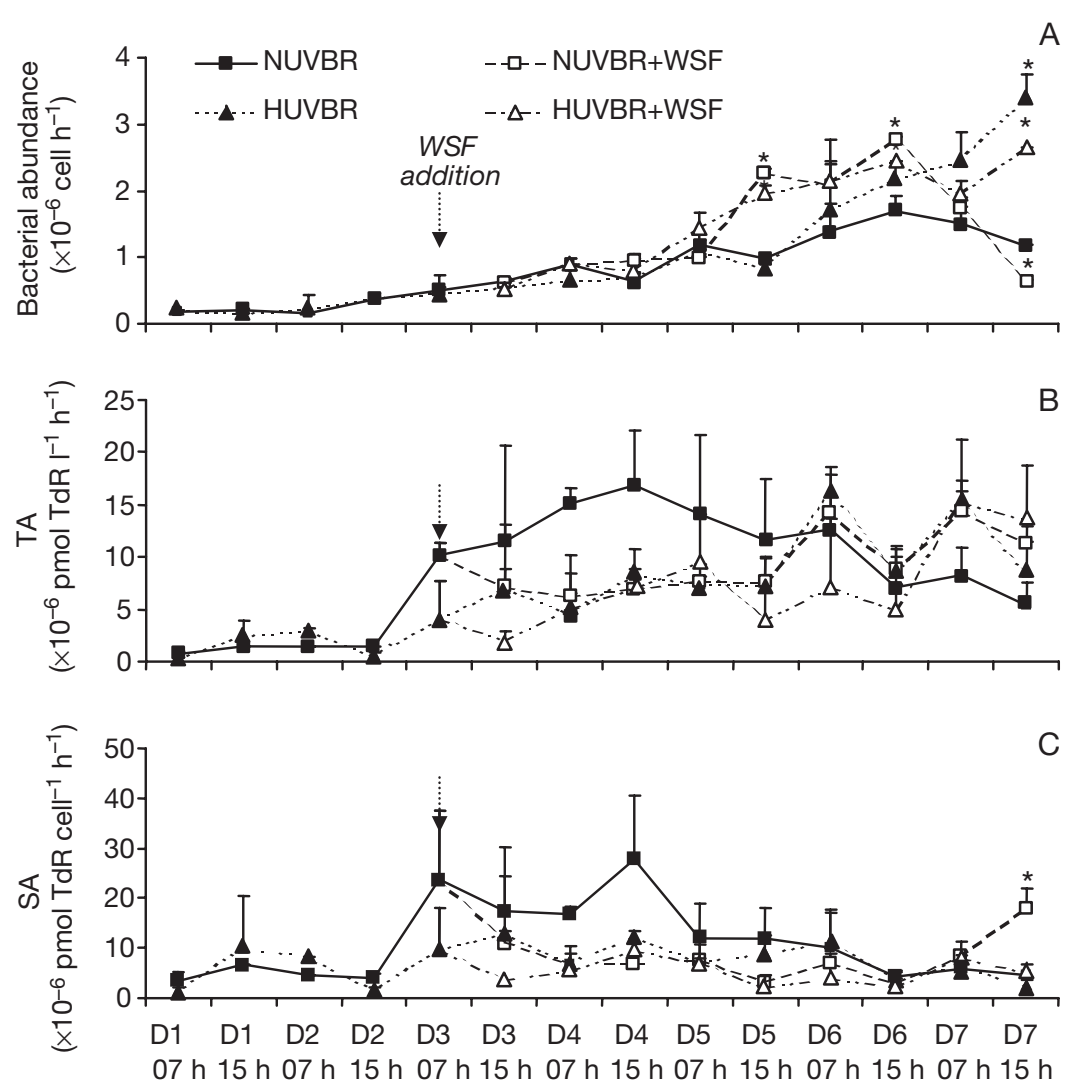

Day of experiment

Fig. 9 Temporal changes (means $\pm \mathrm{SD}$ ) in $(\mathrm{A})$ bacterial abundance as tetermined by DAPI-fluorescence counts, (B) total bacterial activity (TA), and (C) specific bacterial activity (SA), determined by thymidine incorpation. *: significant divverences $(p<0.05)$ between treatments and relative to NUVBR
The lowest thymidine incorporation rate observed was ca. 40, 33 and $30 \%$ of the NUVBR treatment on the morning of Day 4, for NUVBR + WSF, HUVBR + WSF, and HUVBR alone, respectively. Thereafter and until the end of the experiment, the thymidine incorporation rate increased continuously for these 3 treatments. Final values of TA were 148, 108 and $58 \%$ higher than for the NUVBR treatment for HUVBR + WSF, NUVBR + WSF and HUVBR treatments, respectively.

Cellular rates of TdR incorporation (specific activity, SA) are shown in Fig. 9C. As for TA, SA values were higher for NUVBR from Days 3 to 5 than for HUVBR, NUVBR + WSF and HUVBR + WSF. A periodical pattern was observed for these last 3 treatments from Day 5 onward, with SA values higher in the morning and lower in mid-afternoon. By the end of the experiment, SA values in NUVBR + WSF, HUVBR + WSF, NUVBR, and HUVBR, were $1.8 \times 10^{-5}, 5.09 \times 10^{-6}$, $4.70 \times 10^{-6}$ and $2.58 \times 10^{-6} \mathrm{pmol} \mathrm{TdR}$ cell $^{-1} \mathrm{~h}^{-1}$, respectively, representing a ca. $54 \%$ SA inhibition through the UVBR increase in the HUVBR treatment, relative to NUVBR. Similarly, a ca. $72 \%$ SA inhibition was recorded for HUVBR + WSF relative to NUVBR + WSF.
At the beginning of the experiment, the average bacterial rate of TdR incorporation for all treatments (no

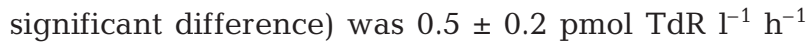
(total activity, TA). On the day of WSF addition (Day 3), a significant difference $(\mathrm{p}<0.05)$ was already observable between the NUVBR (10 pmol TdR $\left.\mathrm{l}^{-1} \mathrm{~h}^{-1}\right)$ and HUVBR ( 4 pmol TdR $\mathrm{l}^{-1} \mathrm{~h}^{-1}$ ) treatments in response to the previous $2 \mathrm{~d}$ UVBR exposure (Fig. 9B). MANOVA showed a day $\times$ WSF effect and a day $\times$ UVBR effect $(p<0.01)$. No interaction between the 2 stresses with time was recorded.

Thereafter, TA increased rapidly in NUVBR without WSF from the morning of Day $3(10.14 \pm 1.22 \mathrm{pmol}$ TdR

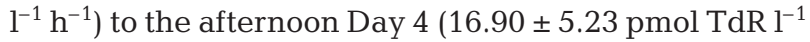
$\mathrm{h}^{-1}$ ), remained relatively stable until Day 6, and then decreased again during the last $48 \mathrm{~h}$ to a final value of $5.43 \pm 2.11$ pmol TdR $\mathrm{l}^{-1} \mathrm{~h}^{-1}$ (Fig. 9B). TA did not show any pattern for the other treatments until the afternoon of Day $5 \mathrm{pm}$, when a periodic pattern became evident, with higher values in the morning, and lower values in mid-afternoon.

\section{DISCUSSION}

The combined effects of ultraviolet light and polycyclic aromatic hydrocarbons (PAHs) have previously been demonstrated in laboratory experiments for individual, well-characterized aquatic species and specific PAHs at concentrations generally higher than those occurring naturally in surface waters (Huang et al. 1993, Marwood et al. 1999, Diamond et al. 2000). Moreover, the use of a single $\mathrm{PAH}$ with 1 species (or even a group of species) is arguably poorly representative of field conditions, which comprise numerous PAHs and PAH-degradation products and ecological assemblages of species. To date, there have been no in situ studies that have clearly and directly assessed ecological effects of co-exposure to UVBR and PAHs on natural populations (McDonald \& Chapman 2002). In the present investigation, the microcosm approach proved a useful outdoor exposure system, in which a natural plankton assemblage was exposed to sunlight and artificially enhanced UVBR simulating ozone 
depletion, and also to a realistic amount of dissolved hydrocarbons in the water column - as often observed after an oil spill (Boehm \& Fiest 1982).

In the absence of an enhanced UVBR level, added dissolved hydrocarbons resulted in negative and significant effects on the natural plankton assemblage. UVBR also induced negative effects, but to a lesser extent, and the combination of dissolved PAHs and UVBR resulted in no significant additive or synergistic effects. This study provides, therefore, the first evidence of a non-synergistic interaction between both stresses, and suggests that the strong deleterious effects of soluble petroleum hydrocarbons can completely mask UVBR-induced effects on marine microorganisms .

\section{Relevance of UVBR exposure levels}

The fluorescent light tubes provided a significant increase in the most damaging short UVB wavelengths. The enhanced UVBR treatments were adjusted to represent UVBR levels likely to occur under $60 \%$ ozone-depletion conditions at the specific site, according to the model of Diaz et al. (2000). This value represents the maximum reported UVBR increase measured during an ozone-hole event on sites such as Patagonia in Southern Argentina (Kirchhoff et al. 1997). The relative weighted enhancement in the present study (2.15) was greater than the relative enhancement (1.24) associated with the ozone hole over Antarctica (Cullen et al. 1992). However, the increased irradiance was attenuated throughout the water column, and at half-depth of the microcosms, the plankton cells were subjected to only $15 \%$ of the surface-enhanced UVBR level while receiving $82 \%$ of the surface PAR. This light attenuation in the water column of the mesocosms was representative of the natural ecosystem, for which Kuhn et al. (1999) reported $K_{\mathrm{d}}$ values ranging between 0.7 to $4.5 \mathrm{~m}^{-1}$ with corresponding depth penetration between 6.6 and $1 \mathrm{~m}$. For PAR, the $K_{\mathrm{d}}$ value was $0.57 \mathrm{~m}^{-1}$, i.e. 8.92 $\mathrm{m}$ depth of $1 \%$ light. In the St. Lawrence Estuary, this value ranged from of 0.29 to $0.53 \mathrm{~m}^{-1}(1 \%$ surface PAR at 8.6 to $16.0 \mathrm{~m}$ ) in July 1984 (Levasseur et al. 1984).

\section{Relevance of WSF toxicity}

Most known toxic constituents of petroleum are relatively water-soluble. Consequently, particular attention was paid to its water-extractable fraction, and our results are consistent with previously reported data for different WSF crude oils (Saeed et al. 1998, Saeed \&
Al-Mutairi 2000). Naphthalene is always present, and levels of monomethyl-naphthalenes (2 isomers) are always higher than the level of naphthalene itself. Moreover, these PAHs are responsible for most of the toxic effects in marine organisms (Sæthre et al. 1984). On the other hand, the potential for photoinduced toxicity of PAHs has been related to their molecular structure (Mekenyan et al. 1994), and if bioaccumulated in larger amounts than other more phototoxic products, naphthalene and its analogs may exhibit a phototoxicity that is relatively greater than expected (Ren et al. 1994). Moreover, the higher UVBR doses applied in the HUVBR treatments would tend to enhance the phototoxicity of these compounds (Mekenyan et al. 1994). The WSF used in our experiment is therefore expected to cause phytotoxicity and photoinduced toxicity in natural assemblages.

After addition of WSF to the microcosms, naphthalene and its analogs were no longer detected in the water samples during the experiment because of their very low concentrations (near to the detection limit of the analytic method used) (Table 3). However, Siron et al. (1996) reported that a WSF concentration lower than $0.8 \mathrm{mg} \mathrm{l}^{-1}$ inhibited phytoplankton growth rate, confirming the high phytotoxicity of WSF crude oil, in which naphthalene and its analogs are the major toxic components, even at low concentrations. It is possible that these compounds were readily taken up by the cells, resulting in a rapid decrease in water concentrations to below the detection limit of the technique. Wolfe et al. (1998) also observed an initial rapid association of naphthalene with a maximum algal uptake within the first hour of exposure.

The hypothesis of a relative enrichment in smaller and fluorescent PAH compounds shown by synchronous spectra under in the HUVBR + WSF treatment (Fig. 4 C,D) was however not supported by identification of PAH metabolites by GC/MS. This could be due to the very low concentrations of these compounds. Moreover, our analytical method only targeted the most nonpolar compounds present, whereas phototoxic manifestation induced by naphthalene and its analogs (the major components of the WSF used in the present investigation) may involve the rapid conversion of these compounds to the corresponding more polar oxidation products including naphtols, ketones and quinones (Bagchi et al. 1998). However, such new fluorescent materials formed during the course of the experiment might not have derived from the WSF used, but from fluorophores, located between 260 and $280 \mathrm{~nm}$ emission wavelengths, which are often prominent in marine waters (De Souza Sierra et al. 1994). Such increase in new fluorophores could be due to either the release of dissolved proteins (Coble et al. 1990) from cell lysis of 
stressed phytoplankton (as reflected in the reduced survival of larger phytoplankton cells), or through UVBR photolysis of the high molecular weight dissolved organic matter into smaller molecular weight photoproducts (Lindell et al. 1995).

Therefore, on the one hand, the negative effects on the plankton assemblage in both WSF-added treatments can be attributed to identified compounds present in the WSF, which are known to be phytotoxic; and on the other hand, the absence of significant and more deleterious effects in the HUVBR + WSF treatment compared with the NUVBR + WSF treatment suggests that PAHs photoproducts were not formed in the present study, or were not detectable, primarily due to overlapping contributions of biological degradation products from cell lysis and/or DOM photodegradation.

\section{Mechanisms and relevance of WSF addition to plankton assemblage}

The high initial concentrations of nutrients favored the development of large cells $(>20 \mu \mathrm{m})$ in the WSFfree treatments during the experiment, whereas the lower total $\mathrm{chl}$ a concentrations in the WSF-added treatments imply a direct impact of dissolved hydrocarbons without UVBR effects on the same phytoplankton fraction. The high susceptibility of diatoms to hydrocarbon compounds has been attributed to the fact that silica is a good absorbent and that the frustules of the diatoms absorb and retain these compounds (Siron et al. 1996). Moreover, being relatively hydrophobic, dissolved PAHs accumulate in the photosynthetic membrane, where they could interfere with chl a synthesis (Duxbury et al. 1997). More specifically, it has been demonstrated that the toxic manifestations induced by naphthalene (i.e. the main compound in the WSF used in the present study) may involve the conversion of this compound to the corresponding naphthoquinones, as well as hydroxylated products including naphthols (Bagchi et al. 1998). Such degradation products can potentially block photosynthesis, especially when plastoquinone $\left(Q_{\mathrm{b}}\right)$ is used as an electron acceptor or donor (Huang et al. 1997), because of their structural similarity with the $Q_{\mathrm{b}}$-binding niche in Photosystem II.

Therefore, following bioaccumulation, dissolved hydrocarbons could interfere with photosynthesis either through direct toxic effects and indirect photosensitization reactions involving reactive oxygen species (ROS). Although major hydrocarbon compounds in our WSF (i.e. naphthalene and its analogs) are not considered to be genotoxic, they can induce the production of ROS (which may enhance lipid peroxidation and cause DNA damage: Bagchi et al. 1998), following their photosensibilization after bioaccumulation (Marwood et al. 1999, Choi \& Oris 2000). The highly reactive quinone derivates may also be responsible for the hydrocarbon-induced oxidative stress and toxic manifestation, as they are know to bind covalently to biological membranes (Sikkema et al. 1995). Whether hydrocarbon-derived quinones produce ROS or whether hydrocarbons such as naphthalene and its metabolites react directly with macromolecules remains to be determined. However, such toxic manifestations resulted in the increase in cell size and reduction in growth rates observed under both WSFadded treatments in the present study. The perturbation of the cell cycle and decrease in growth rates acted together to result in $\sim 80 \%$ mortality of phytoplankton $<20 \mu \mathrm{m}$ in WSF-added treatments relative to the NUVBR treatment.

Following WSF addition under both NUVBR and HUVBR light treatments, deleterious effects of dissolved hydrocarbons were also observed on the bacterial assemblage, with lower total (TA) and specific (SA) bacterial activities until Day 5. Major WSF compounds (i.e. naphthalene and its derivates) have been shown to induce a longer lag-phase in bacterial growth (Garcia et al. 1998). By the end of the experiment, increased bacterial activity was observed in the HUVBR treatment relative to the NUVBR treatment, suggesting an increase in carbon supply. Such additional carbon source could come from the dissolved hydrocarbons themselves (Nigam et al. 1996) as well as from the release of DOM from WSF-stressed phytoplankton cells. Such an increase in bacterial growth substrates could have resulted in the acclimation of the bacterial assemblage to the elevated toxicity of the medium, as suggested by Garcia et al. (1998), as well as in an adaptation through changes in species composition. However, WSF addition also resulted in increasing bacterial abundance followed by a decrease at the end of the experiment. This decrease could be ascribable to grazing by heterotrophic flagellates: dissolved hydrocarbons as an additional carbon supply supported an increase in the number of bacteria, which in turn probably accelerated the growth of bacterial grazers (Yamada et al. 2003).

\section{Mechanisms and relevance of enhanced UVBR to plankton assemblage}

The absence of significant differences in chl a concentrations between the NUVBR and HUVBR treatments in the present study has previously been reported (Mousseau et al. 2000, Wängberg et al. 2001) 
and attributed to the fact that diatoms are more resistant to UVR exposure than other phytoplankton groups (Karentz et al. 1991, Helbling et al. 1996). However, significant differences were observed between both UVBR treatments in the total abundance of cells $<20 \mu \mathrm{m}$. The vulnerability of the smallest phytoplankton fractions has already been documented by Belzile et al. (1998), who demonstrated no UVBR effects on total chl a concentrations, but subtle UVBR effects on specific groups of organisms (5 to $20 \mu \mathrm{m}$ cells). Our results will therefore reflect subtle direct UVBR stress on this smaller phytoplankton fraction, as large herbivores were excluded from the present study and no significant differences were observed in the nutrient status until the last day of the experiment.

The cellular mechanisms underlying the observed decrease in abundance of phytoplankton cell $<20 \mu \mathrm{m}$ could range from ultraviolet-induced DNA damage and subsequent cell-cycle perturbations such as increased cell size and reduced in growth rate (Karentz et al. 1991, Buma et al. 1996, 2001), to inactivation of Photosystem II reaction centers (Marwood et al. 2000). The HUVBR treatment induced a lower growth rate and larger cell size, but the absence of significance suggested that UVBR was not enough to ultimately induce such physiological perturbations. It is likely that repair-processes and protection and/or tolerance strategies may also play a significant role, as well as shifts from UVBR-sensitive species toward more UVBR-tolerant species without necessarily a change in total biomass (i.e. chl a concentrations).

Although UVBR effects are subtle and affect only the smallest fraction of the phytoplankton assemblage, they seem to have been sufficient to induce a positive feedback in bacterial abundance. This seemingly positive effect resulted in an increased bacterial abundance, probably due to the release of DOM from UVBR-stressed phytoplankton cells (MalinskyRushansky \& Legrand 1996). Under UVBR stress, bacteria could also be favored through an UVBR-induced decrease in bacterivory (Chatila et al. 2001). However, the lower bacterial activities in the HUVBR treatment relative to the NUVBR treatment (Fig. 9) also indicate direct negative effects of UVBR. UVBR has previously been demonstrated to induce DNA damage, with the formation of thymine dimmers (Jeffrey et al. 1996), with such cellular damage being correlated to a significant reduction in bacterial activities (Aas et al. 1996, Boelen et al. 2002). Therefore, the overall response of the bacterial assemblage to the UVBR stress in the present study was the net result of direct negative effects during the first days of the experiment and a positive feedback of deleterious effects of UVBR on other trophic levels at the end of the experiment.

\section{Relevance of combined effects of WSF and enhanced UVBR}

The present study has demonstrated that (1) a realistic amount of dissolved hydrocarbons simulating an oil-spill event induced important deleterious effects on a natural plankton assemblage, and (2) an increase in UVBR levels resulted in subtle damage, more specifically to the smallest phytoplankton fraction $(<20 \mu \mathrm{m})$. Moreover, the bacterioplankton response seemed to be additionally regulated by the effects of UVBR on predation pressure. Bacterial grazers could be more sensitive to enhanced UVBR than to WSF, resulting in a positive feedback in bacterial abundance under both HUVBR treatments. The co-occurrence of both stresses would therefore be expected to exacerbate each of these individual effects. However, no significant differences between both WSF-added treatments under the 2 different UVBR conditions and no significant interaction between WSF and UVBR were observed. Our results indicate that the deleterious effects of dissolved hydrocarbons on the natural plankton assemblage exceeded the potential deleterious effects of UVBR, resulting in no measurable effect (i.e. additive or synergistic effects) due to the co-occurrence of both stresses. This study proves, therefore, that the coexposure to dissolved hydrocarbons and enhanced UVB does not increase deleterious and biological effects by additive or antagonistic interactions, in contrast to UVB and other environmental factors such as nutrients or temperature.

As previously pointed out, the concentrations of dissolved hydrocarbons used in this study were representative of an oil-spill event, and synergistic or additive effects could probably occur at lower hydrocarbon concentrations (i.e. chronic inputs into aquatic systems) representative of more typical situations in coastal areas. However, the experimental approach used here cannot support the latter speculation.

Acknowledgements. This work was supported by a National Sciences and Engineering Research Council of Canada (NSERC) grant and by the Fonds FCAR of Québec to S.D. and E.P. It is a contribution to an international research program of the Inter-American Institute for Global Change Research (IAI). We would like to acknowledge Dr. S. Diaz, S. Roy and B. Klein for providing radiation data, and K. Lacoste for his assistance in the experiments. This study is a contribution to the Institut des Science de la Mer de Rimouski (ISMER) and Québec-Océan network.

\section{LITERATURE CITED}

Aas P, Lyons MM, Pledger R, Mitchell DL, Jeffrey WH (1996) Inhibition of bacterial activities by solar radiation in nearshore waters and the Gulf of Mexico. Aquat Microb Ecol 11:229-238 
API (American Petroleum Institute) (1986) The role of chemical dispersants in oil spill control. American Petroleum Institute, Washington, DC

Bagchi M, Bagchi D, Balmoori J, Ye X, Stohs SJ (1998) Naphthalene-induced oxidative stress and DNA damage in cultured macrophage J774A.1 cells. Free Radic Biol Med 25:137-143

Belzile C, Demers S, Lean DRS, Mostajir B and 6 others (1998) An experimental tool to study the effects of ultraviolet radiation on plankton communities: a mesocosm approach. Environ Technol 19:667-682

Bergmann T, Richardson TL, Paerl HW, Pinckney JL, Schofield O (2002) Synergy of light and nutrients on the photosynthetic efficiency of phytoplankton populations from the Neuse River Estuary, North Carolina. J Plankton Res 24:923-933

Boehm PD, Fiest DL (1982) Subsurface distributions of petroleum from an offshore well blowout. The Ixtoc I Blowout, Bay of Campeche. Environ Sci Technol 16:67-74

Boelen P, Post AF, Weldhuis MJW, Buma AGJ (2002) Diel patterns of UVBR-induced DNA damage in picoplankton size fractions from the Gulf of Aqaba, Red Sea. Microb Ecol 44: 164-174

Buma AGJ, Van Hannen EJ, Roza L, Veldhuis MJW, Gieskes WWC (1996) Monitoring ultraviolet-B induced DNA damage in individual diatom cells by immunofluorescent thymine dimer detection. J Phycol $31: 314-321$

Buma AGJ, Engelen AH, Gieskes WWC (1997) Wavelengthdependent induction of thymine dimers and growth rate reduction in the marine diatom Cyclotella sp. exposed to ultraviolet radiation. Mar Ecol Prog Ser 153:91-97

Buma AGJ, Helbling EW, Karin de Boer M, Villafañe VE (2001) Patterns of DNA damage and photoinhibition in temperate South-Atlantic picophytoplankton exposed to solar ultraviolet radiation. J Photochem Photobiol 62:9-18

Chatila K, Demers S, Mostajir B, Gosselin M, Chanut JP, Monfort P, Bird D (2001) The responses of a natural bacterioplankton community to different levels of ultraviolet-B radiation: a food web perspective. Microb Ecol 41: $56-68$

Choi J, Oris JT (2000) Evidence of oxidative stress in bluegill sunfish (Lepomis macrochirus) liver microsomes simultaneously exposed to solar ultraviolet radiation and anthracene. Environ Toxicol Chem 19:1795-1799

Coble PG, Green SA, Blough NV, Gagosian RB (1990) Characterization of dissolved organic matter in the Black Sea by fluorescence spectroscopy. Nature 348:432-434

Cullen JJ, Neale PJ (1997) Biological weighting functions for describing the effects of ultraviolet radiation on aquatic ecosystems. In: Häder DP (ed) Effects of ozone depletion on aquatic ecosystems, RG Landes, Georgetown, TX, p $97-118$

Cullen JJ, Neale PJ, Lesser MP (1992) Biological weighting function for the inhibition of phytoplankton photosynthesis by ultraviolet radiation. Science 258:646-650

De Souza Sierra MM, Donard OFX, Lamotte M, Belin C, Ewald M (1994) Fluorescence spectroscopy of coastal and marine waters. Mar Chem 47:127-144

Diamond SA, Mount DR, Burkhard LP, Ankley GT, Makynen EA, Leonard EN (2000) Effect of irradiance spectra on the photoinduced toxicity of three polycyclic aromatic hydrocarbons. Environ Toxicol Chem 19:1389-1396

Diaz S, Deferrari G, Martinioni D, Oberto A (2000) Regression analysis of biologically effective integrated irradiances versus ozone, clouds and geometric factors. J Atmos Solar Terrest Phys 62:629-638

Duxbury CL, Dixon DG, Greenberg BM (1997) Effects of simulated solar radiation on the bioaccumulation of polycyclic aromatic hydrocarbons by the duckweed Lemna gibba. Environ Toxicol Chem 16:1739-1748

Fauchot J, Gosselin M, Levasseur M, Mostajir B, Belzile C, Demers S, Roy S, Villegas PZ (2000) Influence of UV-B radiation on nitrogen utilization by a natural assemblage of phytoplankton. J Phycol 36:484-496

Fuhrman JA, Azam F (1982) Thymidine incorporation as a measure of heterotrophic bacterioplankton production in marine surface waters: evaluation and field results. Mar Biol 66:109-120

Garcia EM, Siegert IG, Suarez P (1998) Toxicity assays and naphthalene utilization by natural bacteria selected in marine environments. Bull Environ Contam Toxicol 61: 0370-0377

Helbling EW, Villafañe VE, Ferrario M, Hom-Hansen O (1992) Impact of natural ultraviolet radiation on rates of photosynthesis and on specific marine phytoplankton species. Mar Ecol Prog Ser 80:89-100

Helbling EW, Chalker BE, Dunlap WC, Holm-Hansen O, Villafane VE (1996) Photoacclimatation of Antarctic marine diatoms to solar ultraviolet radiation. J Exp Mar Biol Ecol 204:85-101

Huang XD, Dixon DG, Greenberg BM (1993) Impacts of ultraviolet radiation and photomodification on the toxicity of PAHs to the higher plant Lemna gibba L. G-3 (duckweed). Environ Toxicol Chem 12:1067-1077

Huang XD, Krylov SN, Ren L, McConkey BJ, Dixon DG, Greenberg BM (1997) Mechanistic quantitative structure-activity relationship model for the photoinduced toxicity of polycyclic aromatic hydrocarbons: II. An empirical model for the toxicity of 16 polycyclic aromatic hydrocarbons to the duckweed Lemna gibba L. G-3. Environ Toxicol Chem 16:2296-2303

Jeffrey WHM, Ledger RJ, Aas P, Hager S, Coffin RB, Von Haven R, Mitchell DL (1996) Diel and depth profiles of DNA photodamage in bacterioplankton exposed to ambient solar ultraviolet radiation. Mar Ecol Prog Ser 137: 283-291

Karentz D, Cleaver JE, Mitchell DL (1991) Cell survival characteristics and molecular responses of Antarctic phytoplankton to ultraviolet-B radiation. J Phycol 27:326-341

Kirchhoff VWJH, Zamorano F, Casiccia C (1997) UV-B enhancements at Punta Arenas, Chile. J Photochem Photobiol B 38:174-177

Kuhn P, Browman H, McArthur B, St-Pierre JF (1999) Penetration of ultraviolet radiation in the waters of the estuary and Gulf of St. Lawrence. Limnol Oceanogr 44:710-7169

Levasseur M, Therriault JC, Legendre L (1984) Hierarchical control of phytoplankton succession by physical factors. Mar Ecol Prog Ser 19:211-222

Liess M, Champeau O, Riddle M, Schulz R, Duquesne S (2001) Combined effects of ultraviolet-B radiation and food storage on the sensitivity of the Antarctic amphipod Paramoera walkeri to copper. Environ Toxicol Chem 20: 2088-2092

Lindell MJ, Granéli W, Tranvik LJ (1995) Enhanced bacterial growth in response to photochemical transformation of dissolved organic matter. Limnol Oceanogr 40:195-199

Longhi ML (2003) L'influence de l'état nutritionnel du phytoplancton sur la réponse au rayonnement UV-B à différentes latitudes, MSc thesis, Université du Québec, Rimouski

Malinsky-Rushansky NZ, Legrand C (1996) Excretion of dissolved organic carbon by phytoplankton of different sizes and subsequent bacterial uptake. Mar Ecol Prog Ser 132: $249-255$ 
Mallakin A, McConkey BJ, Miao G, McKibben B, Snieckus V, Dixon DG, Greenberg BM (1998) Impacts of structural photomodification on the toxicity of environmental contaminants: anthracene photooxidation products. Ecotoxicol Environ Saf 43:204-212

Marwood CA, Smith REH, Solomon KR, Charlton MN, Greenberg BM (1999) Intact and photomodified polycyclic aromatic hydrocarbons inhibit photosynthesis in natural assemblages of Lake Erie phytoplankton exposed to solar radiation. Ecotoxicol Environ Saf 44:322-327

Marwood CA, Smith REH, Furgal JA, Charlton MN, Solomon KR, Greenberg BM (2000) Photoinhibition of natural phytoplankton assemblages in Lake Erie exposed to solar ultraviolet radiation. Can J Fish Aquat Sci 57:371-379

McConkey BJ, Duxbury CL, Dixon DG, Greenberg BM (1997) Toxicity of PAH photooxidation product to the bacteria Photobacterium phosphoreum and the duckweed Lemna gibba: effects of phenanthrene and its primary photoproduct, phenanthrenequinone. Environ Toxicol Chem 16:892-899

McDonald BG, Chapman PM (2002) PAH phototoxicity - an ecologically irrelevant phenomen? Mar Pollut Bull 44: 1321-1326

Mekenyan OG, Ankley GT, Veith GD, Call DJ (1994) QSAR estimates of excited states and photoinduced acute toxicity of polycyclic aromatic hydrocarbons. Environ Res 2: 237-247

Mostajir B, Demers S, de Mora S, Belzile C and 6 others (1999a) Experimental test of the effect of ultraviolet-B radiation in a plankton community. Limnol Oceanogr 44: 586-596

Mostajir B, Sime-Ngando T, Demers S, Belzile C and 7 others (1999b) Ecological implications of changes in cell size and photosynthetic capacity of marine Prymnesiophyceae induced by ultraviolet-B radiation. Mar Ecol Prog Ser 187: 89-100

Mousseau L, Gosselin M, Levasseur M, Demers S, Fauchot J, Roy S, Villegas PZ, Mostajir B (2000) Effects of ultraviolet$B$ radiation on simultaneous carbon and nitrogen transport rates by estuarine phytoplankton during a week-long mesocosm study. Mar Ecol Prog Ser 199:69-81

Müller-Niklas G, Heissenberger A, Puškaric S, Herndl GJ (1995) Ultraviolet-B radiation and bacterial metabolism in coastal waters. Aquat Microb Ecol 9:111-116

Neale PJ, Lesser MP, Cullen JJ (1994) Effects of ultraviolet radiation on the photosynthesis of phytoplankton in the vicinity of McMurdo station, Antarctica. In: Weiler CS, Penhale PA (eds) Ultraviolet radiation in Antarctica: measurements and biological effects. Antartic Res Ser 62. American Geophysical Union, Washington, DC, p 125-142

Neale PJ, Cullen JJ, Davis RF (1998) Inhibition of marine photosynthesis by ultraviolet radiation: variable sensitivity of phytoplankton in the Weddell-Scotia confluence during the austral spring. Limnol Oceanogr 43:433-448

Nigam P, Banat IM, Marchant R, Singh D (1998) Degradation of naphthalene by bacterial cultures. Environ Int 24:671: 677

OBS (Ocean Studies Board) (2003) Oil in the sea. III: inputs, fates, and effects. Committee on oil in the sea: inputs, fates, and effects, National Research Council of Canada, Ottawa

Editorial responsibility: Otto Kinne (Editor-in-Chief), Oldendorf/Luhe, Germany
Parsons TR, Maita Y, Lalli LM (1984) A manual of chemical and biological methods for seawater analysis, Pergamon Press, Toronto

Ren L, Huang XD, McConkey BJ, Dixon DG, Greenberg BM (1994) Photoinduced toxicity of three polycyclic aromatic hydrocarbons (fluoranthene, pyrene and naphthalene) to the duckweed Lemna gibba L.G-3. Ecotoxicol Environ Saf 28:160-171

Saeed T, Al-Mutairi M (2000) Comparative composition of polycyclic aromatic hydrocarbons (PAHs) in the sea watersoluble fractions of different Kuwaiti crude oils. Adv Environ Res 4:141-145

Saeed T, Al-Mutairi M, Ali LN, Al-Obaid T, Beg MU (1998) The effect of temperature on the composition and relative toxicity of the water-soluble fraction of Kuwait crude oil (export) in the seawater. Int J Environ Anal Chem 72: $275-287$

Sæthre LJ, Falk-Petersen IB, Sydnes LK, Lønning S, Naley AM (1984) Toxicity and chemical reactivity of naphthalene and methylnaphthalenes. Aquat Toxicol (Amst) 5:291-306

Scheiner SM, Gurevitch J (1993) Design and analysis of ecological experiments, Chapman \& Hall, London

Schindell DT, Rind D, Lonergan P (1998) Increased polar stratospheric ozone losses and delayed eventual recovery owing to increasing greenhouse-gas concentrations. Nature 392:589-592

Sikkema J, de Bont JAM, Poolman B (1995) Mechanisms of membrane toxicity of hydrocarbons. Microbiol Rev 59: 201-222

Siron R, Giusti G (1990) Hydrocarbon pollution in particlerich waters (Gulf of Fos-sur-Mer): comparative study of extraction procedures. Mar Chem 30:379-388

Siron R, Pelletier É, Roy S (1996) Effects of dispersed and adsorbed crude oil on microalgal and bacterial communities of cold seawater. Ecotoxicology 5:229-251

Smith DC, Azam F (1992) A simple, economical method for measuring bacterial protein synthesis rates in sweater using ${ }^{3} \mathrm{H}$-leucine. Mar Microb Food Webs 6:107-114

Vincent WF, Roy S (1993) Solar ultraviolet-B radiation and aquatic primary production: damage, protection and recovery. Environ Res 1:1-12

Wakeham SG (1977) Synchronous fluorescence spectroscopy and its application to indigenous and petroleum-derived hydrocarbons in lacustrine sediments. Environ Sci Technol 11:272-276

Wängberg SÅ, Wulff A, Nilsson C, Stagell U (2001) Impact of UV-B radiation on microalgae and bacteria: a mesocosm study with computer modulated UV-B radiation addition. Aquat Microb Ecol 25:75-86

Wolfe MF, Schwartz GJB, Singaram S, Mielbrecht EE, Tjeerdema RS, Sowby ML (1998) Influence of dispersants on the bioavailability of naphthalene from the wateraccommodated fraction crude oil to the golden-brown algae, Isochrysis galbana. Arch Environ Contam Toxicol 35:274-280

Yamada M, Takada H, Toyoda K, Yoshida A and 6 others (2003) Study on the fate of petroleum-derived polycyclic aromatic hydrocarbons (PAHs) and the effect of chemical dispersant using an enclosed ecosystem, mesocosm. Mar Pollut Bull 47:105-113

Submitted: December 5, 2003; Accepted: October 7, 2004

Proofs received from author(s): May 20, 2005 